\title{
Policing Identities: Cop Decision Making and the Constitution of Citizens
}

\section{Trish Oberweis and Michael Musheno}

We examine police decision making by focusing on police stories and drawing together contemporary thought about identities and police subculture. Our inquiry suggests that police decision making is both improvisational and patterned. Cops are moral agents who tag people with identities as they project identities of their oun. They do engage in raw forms of division or stereotyping, marking some as others to be feared and themselves as protectors of society, while exercising their coercive powers to punish "the bad." Due, in part, to the many ways that they identify themselves, cops also connect with people as unique individuals, including individuals whose categorical identities (e.g., drug dealers) put them at the margins of society. Rather than using their coercive powers to repress these individuals, cops infuse them with certain virtues (e.g., good family men) while cutting them breaks. As they complicate representations of themselves, cops also project complex notions of law and legality. Moral discourse seems to infuse their judgments, while they invoke law strategically as a tool to enforce their moral judgments.

The marginalistic integration of individuals in the state's utility is not obtained in the modern state by the form of the ethical community which was characteristic of the Greek city. It is obtained in this new

Trish Oberweis is the project manager at the American Justice Institute, San Francisco. Michael Musheno is professor of justice studies and public affairs and director of the Center for Urban Inquiry at Arizona State University. The authors are grateful to M. A. Bortner, Steve Herbert, Nancy Jurik, Suzanne Leland, Steven Maynard-Moody, Peter Manning, and the anonymous reviewers for comments on earlier drafts of this manuscript. The research related to this article was supported by a National Science Foundation Grant, Law and Social Sciences Program, Grant number SBR-9511169. 
political rationality by a certain specific technique called then, and at this moment, the police.

-Foucault, The Political Technology of Individuals

Police decision making is about policing identities; it is about the constitution of citizens or subjects who are wedded to the administrative apparatus of the state. Examining stories told to us by police officers, we find that police decision making is richly normative and contingent rather than narrowly rule driven and fixed. When police come into contact with citizens, they render moral judgments and concoct actions as they tag people with identities and project identities of their own.

Our identity framework embraces a sociology of culture that treats culture as particular, fractured, and contingent (see Garfinkel 1967; Swidler 1968; Sewell 1992; or Gamson 1992). ${ }^{1}$ It builds on the works specific to police culture that depict cop decision making as "both guided and improvisational" (Shearing and Ericson 1991, 500; also Manning 1989; 'Van Maanen 1978 ) and which recognize that "while coherence is at times obvious in the police world . . conflict is also always present" (Herbert 1997, 146). It draws on police stories as a valuable source for gaining access to the "practical reasoning" of cops engaged in their trade. ${ }^{2}$

Police engage in raw forms of division, marking some as others to be feared (e.g., urban youth gang members), and "put themselves forward as the protectors of 'what is in us more than ourselves,' that is, that which makes us part of the nation" (Salecl 1994, 205). But, police identity is not monolithic, as cops have more than just professional identities. Due, in part, to the many ways they identify themselves, cops connect with people as unique individuals and sometimes defy the simple coercive politics of stereotyping whole groups as "bad." Here, they bond with people whose categorical identities (e.g., illegal aliens, drug dealers) put them at the margins of

1. While others have invoked the importance of "social" identities to understand policing (e.g., Crank 1997, 5), only a few have taken up identities (see, for example, the classic study "The Asshole" by Van Maanan 1978) that are particularly reflective of current thinking about the meaning of identity and how identities are acted out in the everyday.

2. We are guided by Shearing and Ericson, who regard police stories as revealing of cops' practical reasoning or their improvising norms and action (1991, 482). They critique the scholarship on police decision making that presumes action follows rules, even those scholars who have posited the importance of local rules devised at the organizational level and modified by what is often referenced as the "police subculture" (see Manning 1977). Even when scholars have observed the centrality of police stories to the "craft" of policing, they are reluctant to view this form of communication as constitutive of the practical reasoning of cops, in part because police scholars themselves embrace the importance of rule-driven decision making to liberal democracy (see Bayley and Bittner 1984). The significance of stories to understanding normativity and action is well recognized today in sociolegal studies (e.g., Ewick and Silbey 1998; Conley and O'Barr 1998), and in policy inquiry (e.g., Schram and Neisser 1977). We embrace these writings as well as the early groundbreaking work of Shearing and Ericson that is specific to policing, and suggest that police stories reveal the importance of identity and identification to their practical reasoning. 
society. Woven into these improvisations of policing is the recognition of particular individuals as having certain virtues (e.g., good family men), and for them, police act by cutting breaks or by going out of their way to find services.

Classifying some whose categorical identities put them at the margins as worthy individuals needing services or deserving breaks preserves the ranks of society while creating the illusion that individual virtue coupled with timely state action enable movement from the margin to the center of society. We argue that while appearing to be the warm, friendly face of policing, these communicative processes and the exceptionalism they produce are better understood as crucial to the making of state-centered subjects, including citizens who are simultaneously cops.

Before turning to our empirical observations, we lay out our conceptualizations of identity and police. We do this because our perspectives are distinct from mainstream liberal understandings of these topics. As we show below, our perspective is grounded instead in literatures that oppose liberal conceptions of the self and the state.

\section{CONCEPTUALIZING IDENTITY}

Identity is how we come to recognize ourselves and each other. It is the composite of all the multiple and intersecting subject positions that one actor occupies, either by chance or by choice. All of us belong to certain groups; this is to say that we all occupy particular subject positions. The authors are white, well-educated, middle-class heterosexuals. One of us is female and the other is male. Each of these group memberships (middleclass, white, heterosexual, male/female) represents what we are calling a "subject position." These subject positions are constituted through an everchanging process of social meaning making; they often define our expectations as well as what others will expect of us. They provide a way of organizing the social world, of endowing both ourselves and other social actors with more particularized meaning.

Each subject position tells us, to some degree, who we are in relation to others, how to behave, and how to expect others to behave. Thus, subject positions come with expectations that are largely socially agreed upon. They are brought to life through personalized meaning as individuals struggle to take up their positions in ways that both fit with all the other subject positions defining that actor and also which adequately portray any particular subject position, allowing other actors to recognize that position and to act accordingly. For example, the occupational subject position "professor" could be taken up in any number of ways, but to be successful, the performance must be recognized as "professorial." 
We draw a distinction between the term "subject position" and the term "role," which rests on a very different notion of the subject. Subject positions are often categories that might elsewhere be called roles: each term refers to a similar list of words (e.g., professor, woman, etc.). However, in choosing the term "subject position," we are making a different assumption about human actors than we feel the term "role" permits. "Roles" can be chosen and played, exchanged one for another at any time. This implies some human agent, separable from the roles, who is able to put on first one role and then perhaps another. We wish to distance ourselves from this notion of the autonomous self or liberal subject. ${ }^{3}$ Instead, our assumptions are that the actor is always and only the interactive total of her/his subject positions and that there is no self beyond the intertwined subjectivities themselves, no rational actor hiding behind the scenes. The distinction between identities and roles, then, rests on differing assumptions about human subjectivity.

Returning to our example, any particular professor must "be" a professor in ways that are congruent with the other subject positions that that professor holds (e.g., female, heterosexual). Simultaneously, that actor must act in a manner sufficiently congruent with cultural expectations of professors to be recognized as such (e.g., stands in the front of the classroom, gives and grades assignments, and more subtly, is kempt and attentive, carries books or paper or chalk). Thus, the identity process works in both directions, both as a means for actors to know how to act and also as a means to recognize the acts of others. In this way, identity provides a profoundly definitional but largely uncognized framework. From this perspective, then, identity-the total mixture of subject positions and their domains of social connotations-is the flexible bedrock of social order, giving shape and continuity to social relationships, including the relationship to one's self.

Chantal Mouffe offers a more philosophical explanation:

The social agent is constituted by an ensemble of "subject positions" that can never be totally fixed in a closed system of differences. . The "identity" of such a multiple and contradictory subject is therefore always contingent and precarious, temporarily fixed at the intersection of those subject positions and dependent on specific forms of identification. (Mouffe 1995, 33)

Thus, we are never only women or men, only a member of a race or nation or profession. These identifications intersect, ${ }^{4}$ mutually defining the way

3. For a discussion, see Lovibond (1993, 390) or Pauline Marie Rosenau (1992, specifically chap. 3, "Subverting the Subject").

4. Again, we are using the term identification to refer to at least two directions of identity making: we identify ourselves and act accordingly, and we are also identified by others according to how we act/appear. The act of identification in either direction can be more or less 
each subject position becomes part of a nonfixed whole. The ways in which a woman, for example, takes up her femaleness depends on her racial, national, and/or professional positionings, and vice versa. The multiple subject positions that combine to create an identity thus do not coexist, but interexist. They are not separate entities, but rather determine each other in a constant process of formation and transformation, with each new act or performance by the actor. Identity is thus unstable and always momentary, depending on context for clarity.

Our conception of identity insists on this basic dynamism: Identities are interactive. Within the same individual, one particular subject position, in our case "police officer," might be taken up one way by one officer and differently by another officer, depending on what other subject positions (such as race, age, rank, sex, etc.) are interacting with the occupational subject position. It may even be-and often is-taken up differently by the same officer at different times. Across individuals, we see the importance of context. The combination of localized social relations, events, and territory make some particular identities more directly germane and others relevant only indirectly at any particular moment.

Contemporary feminist, queer, and antiracist theory focuses on the ways that identity excludes (see Halley 1993; Hall 1996; or Butler 1990). Descending from a Derridean logic of differánce, these theorists tend to focus largely on who might be excluded from an invocation of a "we," identified as some identity group. As people sharing a given subject position define themselves as a "we," they do so only by simultaneously defining an excluded "they." It is a politics of exclusion based on otherness. In other words, identity tends to be seen as something that divides people across (perhaps arbitrary) attributes. Judith Butler, speaking about the subject of feminism, describes the problem: "The minute that the category of women gets invoked as describing the constituency for which feminism speaks, an internal debate invariably begins over what the descriptive content of that term will be. . . Identity categories are never merely descriptive, but always normative, and as such, exclusionary" (Butler 1992, 15-16). Thus, the terrain of identity is itself not neutral but political. Lines are drawn between "us" and "them," and sides must be taken (indeed, are often experienced as already having been taken). In this sense, identity divides people from each other by its inherent inclusions and exclusions.

However, identity is not only about division. Cornel West suggests that "in talking about identity, we have to begin to look at the various ways in which human beings have constructed their desire for recognition, associ-

rigid. (This is particularly clear in the example of defining "homosexuality" [see Halley 1993]). Subjects can identify themselves and others more or less according to stereotyped images that flatten identities and make rigid what is permeable. In this sense, rigid identifiers are not unlike stereotypes. 
ation and protection over time and in space, always in circumstances not of their own choosing." For West, identity facilitates social coherence. "Identity is about binding," he argues, "and it means, on the one hand, that you can be bound. . . . But it also means that you can be held together" (1995, 16). Thus, identity is a means of connection, too. We pay attention to the ebb and flow of both identity division and connection in the context of the everyday life of policing. Focusing on police officers, we are able to explore the connotations of binding and dividing as microprocesses at work in the construction of state subjects or citizens. We offer identity-driven insight into the informalities of the formal practice of law enforcement, a practice of (re)constituting social order through the "policing" of identity. Our focus includes both citizens and agents as political subjects and conceives of each such that "state agent" and "citizen" are not always mutually exclusive labels. Particularly, police officers are simultaneously state actors and state subjects, or citizens.

\section{ABOUT POLICE AND POLICING}

Louis Althusser has suggested that one primary activity of the state is the reproduction of the relations of production. The police play a crucial role in such reproduction. The state's reiteration of itself requires "a reproduction of its submission to the rules of the established order" (Althusser $1991,127)$. He argues that this process of reproducing social order "is secured by the exercise of State power in the State Apparatuses, on the one hand the (Repressive) State Apparatus, on the other the Ideological State Apparatus" $(1991,141)$. The police play a unique role in this process, as they are both agents of the state as well as state subjects, ideologically constituted in and through the same apparatuses as other subjects. Unlike other subjects, however, police are granted the authority to repressively and violently constitute other subjects within the state's order. Althusser explains that although "the (Repressive) State Apparatus functions massively and predominantly by repression (including physical repression) ... the police also function by ideology both to ensure their own cohesion and reproduction, and in the 'values' they propound externally" $(1991,138)$.

Similarly, Foucault suggests that "the aim of this new art of governing . . . is to reinforce the state itself" $(1988,150)$. He defines the police as governors, ${ }^{5}$ explaining that the "police govern not by the law but by a spe-

5. In tracing the genealogy of police and policing in France and Germany, Foucault shows that from the sixteenth century onward the term police referred to the entire state administrative apparatus and policing to the full range of state administrative activities (1988, 154-55). While the naming of agencies of the state has become more specified and the numbers of state agencies have proliferated from the eighteenth century onward in the West, we take the position that policing remains the task of all state agencies, or in Foucault's words, what the "police are concerned with is men's coexistence in a territory, their relationships to 
cific, a permanent, and a positive intervention in the behavior of individuals" $(1988,159)$. This is how it comes to pass that for Foucault, "the problem of a permanent intervention of the state in social processes, even without the form of the law, is . . characteristic of our modern politics and of political problematics" $(1988,159)$. The police must enforce not only law, but also order. The order police enforce is the state's order.

Rather than protectors of freedom or doers of justice, Foucault's police are protectors and perpetuators of the state. They are among the state's administrators. For him, the population of citizens is "nothing more than what the state takes care of for its own sake" $(1988,160)$. Thus, police as agents of the state are part of the process of creating subjects who, in turn, legitimate the state administrative apparatus and its authority (see also Crank 1994). It is this perspective, a critical perspective of policing, that we embrace. This process of creating subjects includes moments in which the police make connections with citizens and withhold their coercive powers, in effect potentially strengthening the rules through exceptionalism. Through stories about their work, the officers in this study provided illustrations of such moments.

\section{EXAMINING POLICE DECISION MAKING}

To inquire about citizen making, we follow the suggestions of Shearing and Ericson by "examining police stories as stories . . that is, as figurative forms with their own logic" that reveal their "practical reasoning" (Shearing and Ericson 1991, 489). In viewing police stories from the perspective of identity, we suggest that what police think ought to be done and what they do in particular situations depends, in part, on who is involved. ${ }^{6}$ This officer's story illustrates the point.

I got a call for a criminal damage report. Well, it was a dispute between two neighbors. . . . So when I got there, I noticed that the front door had

property, what they produce, what is exchanged in the market, and so on" $(1988,155)$. We focus on the activities of officers in a contemporary police agency while anticipating that they, like their counterparts in other state agencies (e.g., welfare offices), are attendant to the full range of tasks outlined by Foucault in his essay on "The Political Technology of Individuals" (1988). Currently, in collaboration with others, we are conducting parallel research in other state agencies, including a public school and two agencies that deal with vocational rehabilitation.

6. The work of Shearing and Ericson (1991) has been important in challenging the prevailing views that police decision making is structured by an externalized body of rules, and/or that some fixed "police culture" produces "informal" rules that the police then follow. Rather, they see the police as "active participants in the construction of action" and view police culture as "gambits and strategies" rather than some organic whole. Building on Shearing and Ericson, we think that the multiplicity and fluidity of identities provide insight into how police construct action and constitute cultures of policing. We elaborate on this view and relate it to the police literature in the conclusion below. 
lipstick written on it and in real big letters it said, "I know you have my coat and my stereo. You better give it back." It was the size of the whole front door in real dark red lipstick. So I contacted the girl that lived there. She was a white female student whose parents were from the area. She was in her early 20s, nice looking girl, you know, typical college. "Yeah, my neighbor ... she had her stereo stolen and she had her jacket stolen and now she thinks we did it. . . . We know she's the one who wrote the lipstick because she's left messages on our machine saying, 'I know you have my coat and my stereo. . . . You better give it back."

So, basically I had a criminal damage and I could've easily arrested, but

she agreed and the victim agreed that once they leave that evening, she would clean the door and all that, and then she agreed to give the victim $\$ 30$ right there while I was there. . . I don't think on another day I would have arrested in this scenario, but in a lot of criminal damage cases like that, the normal routine would be just to arrest the person. . . I'd have to put a little more thought into the decision had the suspect been male, because physically he'd be more capable of hurting someone there. But, as long as, you know, he didn't seem insane, it didn't seem like there was no threat of violence. I guess I probably would put more thought into the fact that he's male.?

And so we insist: identity matters, in a definitional way. In this case, cultural representations about women and femininity are conjoined with the action the officer (and, by extension, the state) took in defining the situation, its characters, and action plot. The officer's common sense about what course of action he should take was closely related to matters of identity. Police, by virtue of their profession, find themselves in a relatively unique, although certainly not unified position, compared to other American citizens. As agents of the state with coercive powers, police are authoritative directors and choreographers who mark and divide citizens. But these officers are also state subjects, themselves marked and divided by others. Officers, too, are located in other subject positions that may bind them to and divide them from other officers and citizens in an infinite array of interconnections. We suggest that this contradictory location of being both agent and subject of the state shapes how individual officers enforce order as well as law. Below, we examine these thick processes of identity bonds and divisions as they emerge from the stories the officers tell about their work.

We spent six months in the field with the officers of two squads of a police department in a metropolis of the western United States, riding in patrol cars, attending briefings, interviewing. and generally hanging out. ${ }^{8}$

7. Italics indicate passages that were replicated verbatim from the transformed stories told to us by officers. Indented passages that are not italicized are excerpted from the more traditional interviews. See our appendix for a description of the process the stories underwent.

8. We found evidence that police officers may be well disciplined by social scientists. The law enforcement agency we concentrated on, like many others, has given considerable access to researchers. Nearly all the officers in the two squads had the view that ride-alongs and interviews must be the key to advancing our knowledge about their work. They expected 
After getting to know them and letting them get to know us, we selected a subset of 10 officers from the squads not only for their willingness to talk to us and for their verbal animation, but also partially with the goal of diversifying storytellers across several identity categories, such as race, sex, rank, age, and sexual preference. Still, the majority were predictably white, male, street-level officers whom we presumed to be heterosexual. ${ }^{9}$ (See table 1 for breakdowns according to these factors.) As we talked with the officers, other social categories began to emerge as important sources of identity: religion, marital status, parenthood, and even (usually the lack of) membership in the department's special assignment teams.

\section{Characteristics of Police Officers/Storytellers}

\begin{tabular}{ll}
\hline Race & \\
Hispanic & 1 \\
African American & 1 \\
White & 7 \\
Other & 1 \\
Sex & \\
$\quad$ Female & 3 \\
$\quad$ Male & 7 \\
Rank & \\
Officer & 7 \\
Sergeant & 2 \\
Lieutenant & 1 \\
Age & Mid-20s to early 50s \\
Sexual preference & \\
Presumed to be heterosexual & 7 \\
Presumed to be homosexual or bisexual & 2 \\
Not sure & 1 \\
\hline
\end{tabular}

We asked these officers to tell us work-related stories about their interactions with people on the street and in the hallways of their department. ${ }^{10}$ Transcripts of these storytelling sessions, worked into written

us to do a lot of riding, and we did. But we told them that our central interest was in stories, particularly the stories they tell one another. We are quite confident that they did eventually tell us such stories, in part, because we came to hear the same plots repeated and, in some cases, the same events retold by a number of officers. But, all along, the officers thought that the stories had to be secondary to the data we collected through observation and interviews. For a discussion of the historical tendency of researchers to treat stories as insignificant and the implications of this, see Shearing and Ericson 1991, 487-91.

9. Those who mentioned having opposite-sex spouses or children and one man who talked about gays in the department using us-them terminology were presumed to be heterosexual. Those categorized as homo- or bisexual were explicit about such self-identification. . One woman's actions and affiliations at the department suggest that she may be a lesbian, but she never told us so, and so her identity remains ambiguous on this dimension.

10. Narratives or stories, used interchangeably here, are part of people's routine communications (see White 1987). Moreover, they both constitute and carry information about culture, as known by the storyteller. Ewick and Silbey write, "stories people tell about 
narratives, were returned to officers, who added or subtracted information as they wished. Identities of characters were probed where necessary. (See appendix for a more complete description of the research process.) The result was 20 stories about work matters within the department, on the street, and at the intersections between the street and the politics of the department. The remainder of the paper looks at these stories through the framework of identity. ${ }^{11}$ Does identity appear as a salient dimension in the stories and, if so, how does the performance of identities bind people together and how does it divide? How does identity operate in the daily work of police officers? How do they negotiate their own and others' identities in the stories they have chosen to tell? What are the implications of these processes for making citizens? To address these questions, we examined stories first for descriptions of police enacting their occupational identities in various ways, binding them to the community of police officers and other uniformed state agents. Similarly, we examine affirmations of other identities that mediate occupational identification as moments of division between officers. Some stories included descriptions of events or themes that reflected a simultaneous binding and dividing of officers.

\section{COP IDENTITY}

Certainly, our stories reflected a great deal of solidarity among officers, and officers made decisions to protect that unity.

It looked like a plain suicide, which is really all that it was. Tragic suicide, but really nothing more complicated than that. They had to go through his property and other things, his dresser and things of that effect to look for any suicide notes or anything that may have foretold what was to happen. As he was doing this, in a pair of the fireman's socks, he found a small vial of cocaine and instead of turning it over to the wife or letting the family know about it or anything to that effect, he just got a hold of the prosecutor and they decided just to get rid of it and be done with it and throw it away, which is exactly what happened. And here was a case where you really could have turned that thing into a big mess.

themselves and their lives both constitute and interpret those lives; the stories describe the world as it is lived and understood by the storyteller" (Ewick and Silbey 1995, 198). It is in this sense that we use the term story. The assumption that we make is that stories contain elements of Ewick and Silbey's "hegemonic tales," that they represent particular information about doing culture. In this sense, then, "the work is itself already a copy" (Machery, cited in Young 1985). A story, then, is a particularized representation of both the social and the particular.

11. Our intention is not to be reductionist. While our focus is on describing how identity shapes action, certainly we recognize that the actions in the stories are not purely identity driven. For example, Steve Herbert $(1998$; 1997) shows how territory and space define the action norms that police invoke when working the streets. Situational factors of all kinds have a hand in the outcomes. 
The family was never informed of the drug find, and because of the "fraternity" of uniformed emergency workers, the deceased fireman's identity as one of the "good guys" was never challenged. The story of the fireman's suicide and the vial of cocaine marks the territory of police exceptionalism in which officers withhold their coercive powers to serve their invocations of the cause of "justice." In this instance, the officer demonstrates police compassion by referencing concern for "wife" and "family" coping with "tragic" suicide. In making an exception, the officer mutes the routine of police intrusiveness into the lives of friends and lovers of criminal suspects, thus softening the state's coercive capacities, while reinforcing dominant notions of family and constructions of tragedies.

Police routinely engage in this process of identifying who deserves a softening of the state's coercive powers, dividing some from others. Several "suspicious behaviors" were listed as criteria for making these routine distinctions between kinds of people. Language was revealed more than once, with one officer specifically saying that particular phrases, such as "Wut up?" and others that might stereotypically be associated with the voice of African Americans, were criteria of suspiciousness to him. Another officer we'll call Craig talked about objects, particularly cars:

Craig said that everyone is prejudiced, especially police officers. They are not necessarily prejudiced on the basis of skin color or religion, etc., but they are prejudiced against the 'criminal element.' At the time he was telling me this, an older car-maybe an '88 Pontiac Grand Amdrove past. It lacked hub caps and had some parts of a different color, indicating a visit to the junk yard to repair damage. 'There's a criminal's car,' Craig said. Picking out criminals is like a prejudice, he told me, but it's not exactly that. Criminals are not likely to drive around in a Lexus. If they are, those are the hard ones to catch. (Field notes following the ride-along)

Thus, internal to the stories and conversations, the condition of one's car or a simple turn of phrase (assuming language is what the invocation of those phrases was actually about) is enmeshed with the evaluations of people and the actions taken by police. Through this power of determination, police create a gulf between themselves and other citizens.

Despite the potential for isolation from the rest of (the nonpolicing) society, some officers were extremely committed to their professional identities, acting in ways that clearly elevated police status over other identifications. In one story, an officer had to break a love bond in order to preserve his identity as an officer. The officer and dog were the canine unit on call for the department when an armed individual took refuge in a stranger's home, resulting in a volatile situation with potential hostages. 
Lt. Grangier asked our team leader, Gould, what he wanted to do next, and he said that he wanted to send our canine in to check the door entry to see if the suspect was still alive. . . . At that point I had a real kind of sick feeling in my stomach because I knew if the suspect was alive that he was going to kill my dog. I thought about it, and my first thought was I'm not going to send him into a situation like this. . . . I decided to go ahead and send him in because this was a crisis situation. You could be fired at the scene if you refuse a direct order according to the general orders of operations that were written at that time. So, I sent my canine in, and it was kind of a strange one because I had already done over 300 searches with him, building searches with him, and every time I sent him in, I followed right in after him. ... The dog went in about 30 seconds; then I heard a gunshot and a yelp, and I recalled the dog two or three times, and he came back to me. . . . The dog died about a half hour or so later at the vet's. The bullet just bounced around and hit a lot of the main organs and there was nothing they could do. . . . I don't know. Sometimes I wonder about the decision and if it was the right one or not. . . I did not know how much of an impact it would have until it was my dog, how important this dog was to me, how close we really were, how much of a friendship I had with the dog.

The performance of his police identity bound this officer to his fellow officers in such a way that his allegiance to them was maintained throughout the crisis, despite the huge cost. The story illustrates the salience of occupational identity and the partial coercion involved in evoking that salience. At the same time, however, the story reveals that this coercion is internalized as normal. Indeed, the officer acknowledges his own agency in the events and takes responsibility for the decision to send in his dog. Thus, the state is not made to appear as a seamless web of domination, but rather as a legitimate authority to be voluntarily obliged. ${ }^{12}$

Another officer committed herself even more deeply to her identity as a police officer when she shot and killed an assailant. The words she recalls telling herself at the time are revealing about how her actions connect to her identity.

I'm being honest with you here. I was thinking, "Hey, shit. Frankly, I don't want to be here," and for a fleeting moment I just wanted to get the hell out of there. I remember thinking, "There's something wrong with this guy. I want to get the hell out of here." He's coming at us with this weird sort of gait and these black eyes, and there's something wrong with him. He's not listening to us. Let's get the hell out of here, but I knew I couldn't. So, for a fleeting moment we kind of retreat. I realized that, you know, you can't really run away. This is your job. You're going to have to handle it, but I would rather not have been there. Unfortunately that is my job, and I remember having to tell myself, "Susan, this is your job. You have to handle this."

12. Theoretical support comes from Althusser 1991. 
Thus, despite whatever other identities might have been salient, she defined the situation in terms of her police identity and eventually invoked the ultimate power of the state, killing the assailant and clearly committing herself to her police identity: her job, her duty, her performance of self.

Officers are bound together through their identification as officers, as is evident from the examples above. However, the police identity is far from homogenous, as other identifications combine with occupational identity, dividing officers from each other and binding them to other social affiliations. Even the way that different people took up the identity of "officer" reveals the simultaneity of binding and division. Although the following two officets react differently, both.officers must explicitly manage the social isolation and coercive powers that accompany one's identification with policing. One officer told us this during a ride-along:

When I'm off duty at home, ... when we go out to restaurants, I never sit where they put the menu. I always have to sit in certain spots. I have to have a good view of the door, the front door. My back has to be to a corner. It's just a type of ... it's a lifestyle. And that's what I am is a police officer, and I see people off duty that I've arrested before. A lot of times they don't recognize me without my uniform, but I carry a gun everywhere I go.

He seems unable to abandon, even temporarily, his occupational identity. Another officer, however, handles her police identity differently. In field notes after a ride-along with her, one of us wrote this:

She indicated that while going to the university, she found herself deceiving fellow students about her being a police officer. And, even now, while pursuing a master's, she conceals her identity as a cop. She said that being a cop "tags your identity" in the minds of others. People either really like that you are a cop and want to talk about it, or they instantly distance themselves.

Both officers addressed the issue of how they handled themselves while off duty, but each took a different approach, one being consumed by his police identity and the other explicitly and intentionally putting it aside when she leaves work.

We locate "officer" as one among many mutually defining subject positions occupied by an "individual." Thus, to take on police identity or be associated with it is not the same as identifying only as a cop and only with other cops. To bind together is not to homogenize, and to "identify as" is not to become "identical to." Instead, we found differences among officers as they are associated with other identity categories and/or affirm them. 


\section{THE CITIZEN IN THE COP}

Like other studies (i.e., Reuss-Ianni 1983), we found some division between street-level officers and the command staff. The timing of our fieldwork was such that we watched the creation of an association of officers that linked itself to other police and fire fighters' unions in the metropoli$\tan$ area. A very involved officer told us about the union in one of his stories.

I guess it started somewhere around '94-'95. A gentleman was hired to do a reclassification study on the police department. . . . Well, as a result of this study, commanders got a raise, lieutenants got a raise, and sergeants got a raise. The officers were not given a raise. . . . That, in addition to other problems we were having, caused the officers to say, "Let's get to together and discuss what's going on." This time the atmosphere was a lot different. A lot of the officers didn't feel intimidated. There were a lot more things to discuss, and so we held a meeting and about 60 officers showed up . . . .

The general feeling was that we needed to start a union. We talked to a lot of officers and we could see that the support was there. We had another meeting, and we decided that yes, we are going to form an association, and we started collecting names of officers who were interested in joining. We collected over 100 names. Pretty close to 130.

Thus, officers divided across rank lines, in the sense that officers were forming a union that excluded, and perhaps would even be somewhat antagonistic to, command staff.

Other identifications divided officers from each other and bound some to identities that were not occupational. One female officer, for example, told us a story about gender and work.

This is definitely an organization where you can pursue opportunities that are available to you, but . . . when I pursued those opportunities, they haven't always been accepted with open arms. And sometimes it would seem that that's because I'm a woman. There's been openings that I haven't applied for, but that I know other female officers have applied for-for example within the narcotics division - that they simply won't allow a woman into. Actually, I think a woman could do a fine job as a decoy in a lot of those cases. There's been one person who is a peer of mine and our careers have pretty much paralleled. We did go for a couple of the same opportunities whereas maybe he was chosen and I wasn't. I'm not meaning to sound bitter, but after three or four of those kinds of incidents, you've got to kind of wonder what's going on.

Thus, for her, femaleness divided her from other officers, making her a particular kind of officer. This particular officer indicated a very high identification with women outside the department, as well. She told us in her 
initial interview, "I tend to be more, gravitate more towards women. I personally like upwardly mobile women. The climbers, the shakers, the movers."

Moreover, this officer told one of us a story fragment while on a ridealong about how being a female gave her an advantage in some circumstances, helped her identify with and bind herself to the citizens of her community as a woman as much as or more than as an officer. She explained what happened at a domestic violence scene, in which the female victim was extremely upset but apparently not seriously physically injured. The goal was to get the victim into inpatient psychiatric treatment.

It's just kind of a matter of who you latch onto first at the scene. And John latched onto the victim . . . and I ended up with somebody else. So I never saw the victim. Well, John came out of the room and said she's not going to go to Mercyville voluntarily, you know, so now we have to try to get an emergency medical admission and what have you and I said to him, "Well, John, do you mind if I go in and talk to her?" I didn't want to step on his toes or anything like that. And I think it was simply because I was a woman. I stepped in there and she instantly related to me and within two minutes I said to her, "Do you want to go to Mercyville?" and she agreed.

Here, the process of identification binds and divides in complex and fluid ways. The officer was bound to other officers as she arrived at the scene, demonstrated by her knowledge and willingness to address the situation in police style (i.e., each officer "latched onto" somebody at the scene and worked team style to gather information). As she decided that her identity as a woman might be more effective in connecting with the victim, she was divided from the other officers, and simultaneously was bound to another (white) woman. ${ }^{13}$

Race, too, was important to the fabric of identity that divided some officers from others, both on the street and in-house. The matter of race inside the department was addressed very explicitly by one African American officer. He told us a story that began with his career, 16 years ago. It is the story of getting the organization actively involved in antiracism. He began by recounting a racist incident between himself and another officer.

We went to a baseball game, our squad did. . . And that same officer that I felt had been prejudiced was there . . . . So at the baseball game, it was very apparent he had been drinking a lot. He was becoming very belligerent and loud. After the game, we were walking down the walkway to the parking lot and he was behind me, and there was another officer from my squad walking side by side with me with his wife. Well, the officer walking behind

13. This is not to suggest that being a cop can be completely separated from being female, or vice versa, merely that various qualities of membership are highlighted in varying intensities. 
me, he all of the sudden puts his arm on my right shoulder and he says to me, "How much money do you have, nigger?" I was shocked, and I turned around to see who it was, and it was this other officer. I pulled my shoulder away from him, and I just kept walking to my car.

He recognized his division from the rest of the department. I was one of two black officers working in the Glenville Police Department. ${ }^{14}$ The rest of the story was a description of how this officer has tried, without much success, to lead his department to hiring a more diverse group of officers.

I continue to ask, "Why has it taken so long to hire minorities?" So, I'll give you an example. After I was hired, 10 years later, a third black officer was hired. In those 10 years, I continued to ask, "What is the problem? Why can't you find minorities?" The answer was, "We can't find any qualified." I myself was asked to be a recruiter. So I went to a recruitment class the department held and was told that they would send me to college fraternities and various African American associations as a recruiter for the police department. Well, I waited and waited, and pretty close to a year went by and there was nothing.

Again from this story the theme emerges that identity divides some people from others. For this officer, racial affiliation separated him from some fellow officers, but bound him to other minority officers, even if they were not African American in particular. Interestingly, there seemed to be an antagonism rather than a connection between the minority officers, female and male, and a growing population of white lesbian officers, a point we take up below.

A mainstream view among officers seems to be that recruitment into the ranks is highly selective and determined entirely on the basis of merit. The relatively small number of African American and Hispanic police officers in the ranks is believed to be due to a process that judges all applicants blindly and objectively. Officers believe that minorities who apply tend to be less qualified than the pool of Anglo applicants. Some of these officers hold the view that the department fails to recruit qualified minorities, while others take the position that the ratio of minorities to the citizenry is roughly equivalent, indicating a difference in perspective as to whether the department should make more of an effort to find qualified minorities.

Some white male and female officers who hold the view that the process of selecting officers is based on individual merit take a different stance with regard to the way people receive special assignments (e.g., narcotics). Specifically, they believe that special assignments are distributed subjectively, despite similar testing and oral board procedures. According to a

14. Glenville is the fictitious name we've chosen for this police department. 
number of them, special assignment is controlled by a "good old boy" network of senior, white males with rank that enables a select number of officers, mostly white males who hang out with the seniors or come from the ranks of the senior officers, to circulate across assignments. One female officer told us this, in a story about sexist promotional habits:

It does seem that as a woman I have to work a little bit harder to prove myself as far as moving up the ladder around here. . . . Again, in another incident, this person was recently promoted. What happened was that there were opportunities, and a letter of interest was put out, and if anybody wanted to apply for the position, they could do so. Several people did. But this particular officer, I feel, was kind of hand chosen before that process even got done.

In another instance, Officer Bolt, who is young, white, and male, reveals that he, too, felt victimized by a good old boys' network. He told us during an interview that a lot of the competition for promotion is determined by the good old boys. He went to great extremes, even spending a good deal of his off-duty time making himself the most qualified candidate for a promotion, but the job was given to someone Officer Bolt believed to be less deserving.

He didn't want it as much as me and that was obvious because of the preparation that he did and that he didn't do. I had a real problem with that, and that gave me a real bad outlook on the department. You know, it's not what you know; it's who you know. It goes beyond the testing policy.

According to newer-to-the-ranks white males and white female officers hired in the past decade, then, the hiring process that includes them and excludes most minorities is fair, or based on objective standards, while the processes for determining special assignments is unfair, based on the subjective judgments of an identity group marked by whiteness, generational difference, and strong occupational bonds.

Male minority officers see the preferences within special assignments as reflective of a larger system of racial discrimination that includes the recruitment of citizens into the ranks. They do not affiliate with white lesbian officers because of their judgments about recruitment. Some minority officers define the situation in terms of competition, and believe special efforts have been made to recruit lesbians into the department at the expense of minorities. These officers point to the relatively large investment the department makes at gay pride events, by donating time and setting up a recruitment booth that actually generates good contacts, and they compare that investment to the recruitment efforts with regard to minority officers. Several officers made the comment that despite a dire need for Spanish- 
speaking, bicultural officers and the very low number of black officers, "alternative" recruitment efforts were directed more toward homosexuals than toward people of color. An African American officer became active in the recruiting process hoping to rectify the problem:

As far as the recruitment at the university career day, I felt that was a waste because they have our booth next to top law enforcement agencies, like FBI or Big City Police Department and then you have other companies not in law enforcement nearby, like the big engineering companies. And the whole time I was there maybe five minorities stopped by, just to pick up a brochure to look at. I never once got to address the African American groups and fraternities on campus. . . I I think I did it about three times, and each time I did it, I came away with the feeling that this is a waste. The recruitment is not being done right.

\section{PARTICULARIZED INCLUSIONS AND EXCLUSIONS ON THE STREETS AND IN THE HALLWAY}

Race divided officers not just within the ranks. Stories also demonstrated that race matters on the street. But the following stories also reveal the particularized classifications embedded in police decision making and how these means of identification affirm the citizenship of some while excluding others from membership. For example, in a case involving a working-class Hispanic man who confessed to being a marijuana dealer, officers disagreed on how to proceed. Two of the man's marijuana affiliates came to his house to rob and kill him. Due to a great size advantage, Francisco was able to grab his assailants' gun and fire shots at them. The Hispanic officer ${ }^{15}$ who told us the story felt that Francisco had been through enough. Francisco had been traumatized, upset, fearful for his life, and he was just defending himself. Period. He had every right to shoot. He wanted no charges to be brought against Francisco, either regarding his drug violations or for his unsafe firing of a gun.

The marijuana business is dismissed as a class problem, although perhaps the male requirement to provide for one's family may have played into the connection as well.

15. The Hispanic officer defined himself as "working class" in conversations with us and in interview sessions with him. In fact, several officers in the two squads asserted a workingclass identity, to our surprise. They chose the territory of their squads in part because it is inhabited by other "working joes." They referenced other space as alien to their self-identity-affluent neighborhoods full of professionals, doctors, lawyers and scientists-and viewed many calls from such areas as "petty." 
He had $a$ wife and $a$ baby and wasn't able to make ends meet. So he started dealing small amounts of marijuana. . . Francisco was just doing the best he could. These were terrible burdens he had on his back, for a 28-year-old guy. He also had his little sister living with him. She was still in high school. I'm not sure where the parents were, but he was raising his little sister. . . . He had a little brother living with him and his brother was in high school. . . . He had a little family situation set up there and he was trying to make ends meet. I've seen people that have worked hard during their lifetimes, like Francisco had.

The supervisors did not share the officer's view that Francisco should go free. The officer himself points to the intersection of race, ethnicity, and class in narrating the discrepancy of opinion. The supervisors were adamant that Francisco be arrested. I didn't care for that idea. I think [that] to them, Francisco was seen as a semi-literate Hispanic. These were white supervisors making the decision. The connection between the officer and Francisco in this story demonstrates the division among officers across other identity dimensions and the alternative connections that the officer might make as daily decisions are being made and citizens are being identified as criminal or not criminal.

The story of Francisco is, in part, about police exceptionalism-that is, coercive powers are withheld to the benefit of a citizen occupying marginal cultural space. The officer bonded sufficiently with Francisco that he risks severe consequences for negating charges that superiors expected him to file, and he therefore, is acting contrary to his self-interest. At the same time, it is a story about the construction of a political subject who receives his just deserts because he exhibits a work ethic and family commitment that enfolds him-along with the officer as subject-into the mainstream fabric of sociocultural (hard-working immigrant) and normative orderings (just deserts). The benevolence of the police is foregrounded by the officer as agent, and yet, his identification of those who tried to rob and kill Francisco excludes other individuals and marks them as particularly requiring coercive police action. The officer describes one of the "bad guys" this way:

Steve ... deserves trouble. He had been involved in other shootings. Steve had told another homicide detective before that he was untouchable because his family was judicial. [In a different incident,] he pulled up to a stop sign and ran it and saw some people from another car with a gun. They started shooting at him with high-capacity $9 \mathrm{mms}$. Steve seemed to have nine lives. One went across him and hit his girlfriend in the face and eventually she wound up with paralysis and nerve damage. His brother was hit twice in the back of the head in the back seat. . . You'd think that he'd go to the hospital. Not Steve. Steve drives down the street, parks the vehicle, and goes to a safe place and starts changing tires. He's got two bleeding people in his car and he's changing tires. 
The following excerpts from one lieutenant's story highlight the importance of identity in defining an individual as criminal or not.

We have an officer who had a domestic violence situation. I don't want to go into what it was about, but they were having domestic problems. He and his wife were not getting along well. They were in the process of getting a divorce, and things were not going well. There was a very young child involved in it. He [the officer] was just losing it. He made a series of phone calls. Not a good idea, granted. She, of course, filed a police report in Jefferson City. He winds up being charged [and convicted] with making harassing phone calls. Well, she gets linked up with, of all people, an ex-convict, which is not like his [the officer's] thing to decide, but that's who's raising his son now. And his son is still involved, and they're still trying to write the visitation issues. And he starts yelling at her . . . and the next thing you know they're in a big argument in which our officer is probably the aggressor. There's no physical contact or anything. It's just loud. So, they wanted to file a complaint. Now he's convicted again. What do we do with this guy? Two convictions now. Two convictions on a police officer. Is this about his ability to be a police officer, or is this about his broken heart? Wait a minute, let's just put this in the proper perspective. I'm saying this is not a professional issue. It's a personal issue. How is he a police officer when he's convicted of these things? When he comes here, he's a police officer. Well, if we can say about a month after this thing is dealt with that he winds up at a call where he saves somebody's life, then we save face, too. Interesting, eh?

What is compelling about this story is that two men, both convicted of lawbreaking, are identified quite differently by this lieutenant. One is an "ex-convict" whose identity is an added source of frustration, in part, because his status as a convict throws into question his ability to raise a child. At the same time, however, the officer's convictions are the result of a "broken heart," a "personal" rather than "professional" problem. His indignation at having an "ex-convict" raise his son is legitimated by the lieutenant's telling of the story. In this way, the officer's identity as a cop protected him from the social stigma that accompanies being identified by the police as a criminal. He remains an agent of the state while his subject position is constituted as a troubled worker in need of help. The state administrative apparatus, as manifested in the story by the lieutenant, is presented as caring for one of its workers while, at the same time, the territory of coercive engagement is marked in the referencing of another individual as an ex-con.

As a last example of the simultaneous processes of binding and dividing, we turn to the group of lesbians who work in the Glenville Police Department. Because her partner required surgery and after care, a lesbian officer approached her lieutenant, who is also homosexual, and requested a family emergency leave day, which is a paid day reserved for "family" 
emergencies. In the following excerpt, the lieutenant reports what the officer, who we'll call Joan, said:

"I think the right thing for us to do is that I should be afforded the same opportunities toward emergency leave for a family situation as others in this agency are allowed to do." [Joan] reminded me by way of example. A sergeant [Al] had just recently married, maybe four or five years ago. She said, "Here we have a sergeant who's been married four or five years, and he recently took family emergency leave for something. Who knows what it is. Well, I'm here to tell you that me and my partner have been together for over nine years, so I have been involved in a domestic relationship for longer than even [Al], and he gets the paid benefits. Why shouldn't I?" I said, "You're right. You're absolutely right."

The officer got the paid day. She defined her family situation as similar to the situation of a heterosexual officer and his family. The lieutenant accepted this definition. Thus, like the male officer in the department, she was entitled to the benefit. At its core, the officer's argument uses the logic that she, as an officer, should be entitled to the same city benefits that other officers-and one in particular-received, binding her to other officers as a whole and one male officer specifically, for the political end of getting benefits. At the same time, however, making explicit that she is homosexual simultaneously divides her from the exemplified officer, as well as other officers, producing a binary between heterosexual and homosexual officers.

\section{CONCLUSION}

Our analysis suggests that cops' identities as cops are strong, even as officers find different ways to manage their occupational identities. Several of the narratives suggest that occupational identity defines, indeed trumps, other reactions. For example, one of the officers told a story about his inability to abandon, even temporarily, his occupational identity. Even when off duty and at a restaurant with his spouse, he would always sit so as to have a good view of the front door. A female officer's story of killing an assailant is deeply interwoven with her realization about the salience of her cop identity. Other stories reveal the strength of the bonds among officers, including a strong tendency of cops to withhold their coercive powers when dealing with citizen-cops, as was revealed in the story about the police officer who was "the aggressor" in a series of family violence events.

At the same time, our analysis suggests that different cops act out their occupational identities in different ways. For example, contrast the way of the cop who always positions himself to see the front door in a restaurant with that of the cop who conceals her identity as a police officer while 
attending a university. Police are part of an organizational culture, but "different individuals . . . possess different amounts and types of cultural resources" (Herbert 1998, 346).

In addition to drawing on their occupational identities differently, cops are not uniform in the norms and primary values they use to render judgments about citizens and fellow officers. Steve Herbert finds that police officers employ a web of "normative orders," each representing "a set of rules and practices centered on a primary value" $(1998,4)$. He uncovers six normative orderings at work-law, bureaucratic control, adventure/machismo, safety, competence, and morality-and argues that conflicts arise among officers over which set of rules and practices should be used in what street contexts (Herbert 1998, 361-64). Herbert's framework, grounded in the study of space and territoriality, is illuminating, but it gives limited insight into how cops manage their conflicts over norms and the contexts that seem to invite police officers to use one normative order over another. Herbert writes, "Just which order, or combination of orders, will capture a particular officer's allegiance at any given time eludes prediction" $(1998,171)$.

Our work suggests that the invocation of norms is strongly bundled with processes of identification. How cops identify with one another and the people they encounter on the streets is wrapped up or ontologically interwoven with the action norms they invoke. At times, cops use crude notions of "badness" in combination with broad categorizations, denying the uniqueness of individuals, and enfolding them into social categories already marked for exclusion and the invocation of coercion (e.g., homeless vs. homeowner; illegal alien vs. citizeh). Indeed, some report that police have become more skilled in constructing these categories through the invocation of a discourse of war, and use paramilitary strategies to enforce the boundaries they themselves have been active agents in constructing (see Fishman 1978; Ericson 1991; Welch, Fenwick, and Roberts 1998; or Zatz 1987).

At the same time, we draw attention to a more subtle process of identification at work in modern policing that enables management of conflicts. Police engage in an ongoing negotiation of their own subject positions as they interact with fellow officers in the hallways of their department and engage people in the streets. Through the dynamics of binding with the particularities of individuals, cops sometimes withhold their coercive powers, creating moments when they define themselves in relation to civilians with complex identities. Yet, at the same time, these actions divide further, revealing police as highly adept at classification and its attendant political rationality. For example, in the story of Francisco, his violent acts are exempted while he is affirmed as a worthy citizen, due, in part, to his work ethic and family orientation. At the same time, the violence of Francisco's assailants is condemned, and they are vilified as unworthy subjects with 
particularized attributes and pursued with the full force of police coercive capacities.

Even as they are particularistic, the classifications that arise from these subtle processes of binding and dividing reinforce rather than fracture dominating identity tropes (e.g., white middle-class lesbianism) and norms (e.g., justice of deserts). Officers reposition themselves, often moment to moment, in relation to the administrative apparatus they occupy and reveal a range of identities that counter categorical thinking about who cops are. Privileging the particulars of some citizens while at the same time revealing the particularities of their own identities may enable police to generate necessary support from the diversity of working- and middle-class communities occupying contemporary urban space.

As they complicate representations of themselves, cops also project complex notions about law and legality. We are struck by the significance of moral discourse, particularly in contrast to legal discourse, in how cops frame their justifications for action. Cops appear to make judgments about the relativity of people-their similarity or incomprehensibility-more than they tend to evaluate people's actions in relationship to legal codes and rights. Law is often invoked in the stories strategically-that is, as a tool to be used to punish the unworthy or as a hurdle to get around so that the worthy can be helped rather than punished.

Our observation that morality is more significant than law in the practical reasoning of cops could be interpreted as a reflection wholly consistent with contemporary sociolegal thought about "legality." Patricia Ewick and Susan Silbey reference legality as "the meanings, sources of authority, and cultural practices that are commonly recognized as legal, regardless of who employs them or for what ends" $(1998,22)$. Cops are a critical source of legal authority, and their action norms, even when expressed in moral terms, are commonly recognized as legal expressions that carry significant weight. Moreover, some contemporary sociolegal scholars hold that law has no normative center and, instead, is contradictory in what it projects as guiding principles. But we think it is important to pay attention to the salience of normative orderings and agree with Steve Herbert that it is possible to distinguish one from another in tracking the expressive judgments of state agents and citizens alike. Failing to do so is to privilege a normative ordering as having no discernable contours and, ultimately, to risk rendering law meaningless as an intellectual construct. ${ }^{16}$

16. For a different view, see Sarat 1990. 


\section{REFERENCES}

Althusser, Louis. 1991. Ideology and Ideological State Apparatuses (Notes Toward an Investigation)" In Lenin and Philosophy, and Other Essays, trans. Ben Brewster, 121-73. London: New Left Books.

Bayley, David, and Egon Bittner. 1984. Learning the Skills of Policing. Law and Contemporary Problems 47:35-59.

Butler, Judith. 1990. Gender Trouble: Feminism and the Subversion of Identity. New York: Rourledge.

1992. Contingent Foundations: Feminism and the Question of Postmodernism. In Feminists Theorize the Political, ed. Judith Butler and Joan W. Scott, 3-21. New York: Routledge.

Conley, John, and William O'Barr. 1998. Just Words: Law, Language, and Power. Chicago: University of Chicago Press.

Crank, John P. 1994. Watchman and Community: Myth and Institutionalization in Policing. Law and Society Review 28: 325-52.

- 1997. Understanding Police Culture. Cincinnati, Ohio: Anderson Publishing.

Ericson, Richard. 1991. Representing Order: Crime, Law, and Justice in the News Media. Toronto, Ont.: Toronto University Press.

Ewick, Patricia, and Susan Silbey. 1995. Subversive Stories and Hegemonic Tales: Toward a Sociology of Narrative. Law and Society Review, 29:197-227.

- 1998. The Common Place of Law. Chicago: University of Chicago Press.

Fishman, Mark. 1978. Crime Waves as Ideology. Social Problems 25:531-43.

Foucault, Michel. 1988. The Political Technology of Individuals. In Technologies of the Self, ed. Luther H. Martin, Huck Gutman, and Patrick H. Hutton, 145-62. Amherst: University of Massachusetts Press.

Gamson, William. 1992. Talking Politics. New York: Cambridge University Press.

Garfinkel, Harold. 1967. Studies in Ethnomethodology. Englewood Cliffs, N.J.: Prentice Hall.

Hall, Stuart. 1996. Introduction: Who Needs Identity? In Questions of Cultural Identity, ed. Stuart Hall and Paul du Gay, 1-17. London: Sage Press.

Halley, Janet M. 1993. The Construction of Heterosexuality. In Fear of a Queer Planet, ed. Michael Warner, 82-104. Minneapolis: University of Minnesota Press.

Herbert, Steve. 1997. Policing Space: Territoriality and the Los Angeles Police Department. Minneapolis: University of Minnesota Press.

1998. Police Subculture Reconsidered. Criminology 36:343-69.

Lovibond, Sabrina. 1993. Feminism and Postmodernism. In Postmodernism: A Reader, ed. Thomas Docherty, 390-414. New York: Columbia University Press.

Manning, Peter. 1977. Police Work. Cambridge, Mass.: MIT Press.

—. 1989. Occupational Culture. In Encyclopedia of Police Science, ed. William Bailey. New York: Garland.

Meyer, John C. 1995. Tell Me a Story: Eliciting Organizational Values from Narratives. Communication Quarterly 43:210-24.

Mouffe, Chantal. 1995. Democratic Politics and the Question of Identity. In The Identity in Question, ed. John Rajchman, 33-46. New York: Routledge.

Reuss-Ianni, Elizabeth. 1983. Two Cultures of Policing: Street Cops and Management Cops. New Brunswick, N.J.: Transaction Books.

Riessman, Catherine Kohler. 1993. Narrative Analysis. Newbury Park, N.J.: Sage Publications.

Rosenau, Pauline Marie. 1992. Post-Modernism and the Social Sciences: Insights, Inroads, and Intrusions. Princeton, N.J.: Princeton University Press. 
Salecl, Renata. 1994. The Crisis of Identity and the Struggle for New Hegemony in the Former Yugoslavia. In The Making of Political Identity, ed. Ernesto Laclau, 205-32. London: Verso.

Sarat, Austin. 1990. 'The Law is All Over:' Power, Resistence, and the Legal Consciousness of the Welfare Poor. Yale Journal of Law and Humanities 2:343-79.

Schram, Sanford, and Phillip Neisser. 1977. Introduction to Tales of the State. In Tales of the State: Narrative in Contemporary U.S. Politics and Public Policy, ed. Sanford Schram and Phillip Neisser. Oxford, England: Rowman and Littlefield.

Sewell, William. 1992. A Theory of Structure: Duality, Agency and Transformation. American Journal of Sociology 98:1-23.

Shearing, Clifford, and Richard Ericson. 1991. Culture as Figurative Action. British Journal of Sociology 42:482-506.

Swidler, Ann. 1968. Culture in Action: Symbols and Strategies. American Sociological Review 51:273-86.

Van Maanen, John. 1978. The Asshole. In Policing: A View from the Streets, ed. John Van Maanen and Peter Manning. Santa Monica, Calif.: Goodyear Publishing.

Welch, Michael, Melissa Fenwick, and Meredith Roberts. 1998. State Managers, Intellectuals, and the Media: A Context Analysis of Ideology in Experts' Quotes in Feature Newspaper Articles on Crime. Justice Quarterly 15: 219-42.

West, Cornel. 1995. A Matter of Life and Death. In The Identity in Question, ed. John Rajchman, 33-46. New York: Routledge.

White, Hayden. 1987. The Content of the Form. Baltimore, Md.: Johns Hopkins University Press.

Young, Robert, ed. 1985. Untying the Text: A Post-Structuralist Reader. Boston: Routledge and Kegan Paul.

Zatz, Marjorie. 1987. Chicano Youth Gangs and Crime: The Creation of a Moral Panic. Contemporary Crises 2:129-58.

\section{APPENDIX: A WORD ON NARRATIVE METHOD}

Officers from three squads were asked by their superiors to participate in the project. Participating officers took one or both of us on at least one ride-along and were interviewed at that time about their histories and work as police officers as well as about how they define themselves. From these interviews as well as our field notes and experiences, 11 storytellers were chosen. One of these retired, but the remaining 10 agreed to participate. They were asked to tell us stories about faimess and unfairness and how they used their discretion. Stories could pertain to events occurring either inside the department or on the street.

Narrative methods take everyday experience as data. Storytelling is an almost reflexive means to relate personal experiences. Catherine Kohler Riessman explains: "A teller in a conversation takes a listener into a past time or 'world' and recapitulates what happened." $(1993,2)$, giving subjective order to events and experiences. Authorship of the experiences to be included or excluded in a story belongs to the storyteller. Through stories, participants can relate their everyday, subjective experiences. Riessman goes on to suggest that because the "approach gives prominence to human agency and imagination, it is well suited to studies of subjectivity and agency" $(1993,5)$. Moreover, "narratives bridge the gap between daily social interaction and large-scale social structures" (Ewick and Silbey 1995, 198). They navigate between the particular, routine lives of the characters in the story and the broader, sociohistorical context that infuses the specifics of a story with social meaning. Specific everyday events are thus situated into the broader social background from which they emerge. 
Officers themselves decided which of their many work stories to share with us and how such stories should be relayed, deliberately highlighting the events and characters in particular ways. Thus, when officers shared their stories-from the first telling-they constructed them in meaningful ways, laden with the narrator's assumptions about and viewpoints on the events. For example, one officer whose agenda involved getting the department to hire more minorities took advantage of finding a place to speak. He told stories about what he defined as unfair hiring procedures and expressed a gratitude that someone was willing to listen. He used his stories to construct one aspect of the department in order to make his perspective heard. Another officer recognized the political implications of her story when she expressed her concern that a story might paint the department as sexist, which she said she did not want to do, despite her story's explicitly sexist plot.

Finally, a fairly common concern from our storytellers was that their stories would be boring. Several officers (and especially two young white male officers) were very concerned that their stories would not be exciting enough to compare with the image of policing. One rescheduled with Trish at least three times, telling her that he wanted to go back through his computer notes to find sufficiently exciting stories. Even as Trish rode along with this officer, he expressed a concern that the ride-along would be too boring. He said that ordinarily, he would be doing some routine visits to local apartment complexes, making a pitch for the managers to cooperate with the police in a community policing project designed to reduce crime. Thus, the stories, even as they were being recorded for the first time, were careful constructions by officers, with the intention of creating some particular picture (i.e., of racist hiring practices, sexist promotions in an otherwise unsexist organization, or the exciting work of police officers).

Officers told us these stories in tape-recorded sessions, most of which took place in interview rooms at the station or substations. However, one officer held nearly every session in his squad car. Transcripts were created and manipulated from their original (largely one-sided) dialogue into a straight narrative. Basically, this consisted of eliminating some of the repetition that is part of oral communication but that does not read well as written narrative. The other main manipulation was to integrate responses to probes asked at the end of the session at some logical point in the narrative. Such manipulations by the research team do change the story. Simply moving from an oral to a written tradition changes the story. We do not believe that the researchers should have full authorial license to manipulate the stories, yet it seemed imperative to bring the data into a grammatical form that could then be shared on paper. What the officers first constructed as an oral representation, the researchers reconstructed as a written text and then, later, represented through the analytical framework of a binding and dividing identity politics.

Our reconstruction was subject to the storyteller's final approval. Once the story was coherent as a narrative, we returned it to the storyteller for corrections and clarifications. All changes from this session were applied to the story, and the result of this process is what we counted as story data.

Transformations to the story were carefully considered, ${ }^{17}$ Particularly because of the way the stories were solicited, with officers having several days to plan out and even write down a story to tell us (among other reasons), we view the stories as constructed representations. We took the verbiage of the transcript and transformed it into (our version of) a written story. This allowed the additional information gained during follow

17. By contrast, see John C. Meyer's article, "Tell Me a Story" (1995), in which he analyzed interviews. One drawback to using the interviews and determining which pieces within them are to be called stories is that the power to determine lies with the researcher. The two-step process-transforming the interviews into stories and then asking participants to review them-serves as a check on the researchers' creation of data. Although initially it seems counterintuitive, we believe that transforming the stories into a written tradition and giving greater control over what counts as a story to the participants gives them more control over the data than the seemingly less obtrusive method of analyzing interviews for the story fragments that the researchers identify. 
up probes to be inserted at its logical point in the story. It also allowed officers to be comfortable as they read their own texts, making changes here' and there. Thus, officers retained control over their texts. After the interview transcripts were made into narratives, officers reviewed them with the understanding that they were to change anything that was inaccurate or inappropriate. Any changes they made were incorporated into their texts.

Aside from the stories, much of our analysis relied on field notes from the time we spent interacting with officers and their daily routines. These field notes served as backdrops to our understandings and interpretations of the stories. Without the extended period of observation and repeated review of the field notes, we would lack a nuanced understanding of the events of the stories. The most obvious example of the interwoven analysis of the stories and the notes would be that had we not done the observations, we might very well have articulated a professional identity centered on the daily excitement of police work. Instead, we found that daily work time is spent filling out paperwork, waiting for something to happen, or assisting with car breakdowns and other "unexciting" but certainly important aspects of police work. Thus, to thicken our readings of the officer's stories, we drew heavily on each other's field notes, which captured important insights into the kinds of constructions we perceived police to be advocating. 
HeinOnline -- 24 Law \& Soc. Inquiry 9241999 